\title{
Development of LED TV Learning Media in Audio Video Electronics Maintenance and Repair Subjects at Surabaya KAL-1 Vocational School
}

\author{
D M Putra ${ }^{1}$, S Muslim², E Ismayati ${ }^{3}$, M R W Maulana ${ }^{4}$ \\ \{dickyputra16070895009@mhs.unesa.ac.id ${ }^{1}$, suparimuslim@gmail.com², euisheru@gmail.com ${ }^{3}$,
} moh.maulana16070895014@mhs.unesa.ac.id $\left.{ }^{4}\right\}$

\author{
${ }^{1,2,3,4}$ Electrical Engineering Education, Universitas Negeri Surabaya, Indonesia
}

\begin{abstract}
This study aims to: (1) describe the quality of LED TV trainer learning media in Audio Electronics Maintenance and Repair subjects at Surabaya KAL-1 Vocational School; (2) describe the response of students in Audio Video Engineering at Surabaya KAL-1 Vocational School; and (3) analyze the learning outcomes of students of Audio Video Engineering at Surabaya KAL-1 Vocational School. This research was conducted in four stages, namely: (1) preliminary study; (2) designing the design of LED TV trainer learning media; (3) media validation and revision, and (4) empirical testing of LED TV trainer learning media in class XII students of Surabaya KAL-1 Vocational Audio Video Engineering and final revisions. The design of the empirical trial study was conducted using The One Group Pretest-Postest Design. To analyze differences in the average score of learning outcomes before and after being taught using LED TV trainers, the t-test was used. The study found that: (1) the results of the validation of the LED TV trainer learning media obtained an average score of $3.19 ; 3.88$; and 3.69, and declared good/valid so that it is worthy of being used as a learning media; (2) there are differences in the average score of student learning outcomes before and after the learning process using LED TV trainer learning media; and (3) students' responses to the learning process using LED TV trainer learning media were stated positively with the percentage of responses amounting to $84.4 \%$.
\end{abstract}

Keywords: LED TV learning media, student response, learning outcomes, vocational students.

\section{Introduction}

Technology and Vocational Education is an education system that is organized to print Human Resources that have character and competence in certain fields and levels. The government through the Ministry of Education and Culture continues to strive to improve the quality of education in Vocational High Schools (VHS). In the future, VHS graduates are expected to be able to develop entrepreneurship because they have been equipped with the ability to be independent and entrepreneurial, skilled, ready to use, and professional when studying at school.

Vocational High School, built to produce skilled and competent workforce. The Vocational Education education system provides a greater proportion of vocational practice 
activities for students. This is done so that students get used to and are able to develop the potential that is in themselves[1]. vocational education is special education whose programs or subject matter are chosen for anyone who is interested in preparing to work alone or to work as part of a workgroup. Vocational education is also intended to change students' mindsets to be more dynamic. Vocational schools that have a focus on preparing skilled workers are required to provide adequate educational facilities and infrastructure. One of the means of education in question is a means of teaching and learning activities in the classroom. Students and teachers must have interactive learning media that is able to support learning activities in the classroom. The right learning media and in accordance with the characteristics of students are considered capable of providing special stimulation to students in the learning process in the classroom. The learning media in question is learning media that can cover the entire contents of basic competencies and learning indicators[2]. Using media is the key to moving students to higher-level thinking. Therefore, the accuracy of the selection and use of learning media becomes very necessary in the process of practicing vocational students in the classroom.

A good learning media, has standardized criteria, including meeting the conformity aspects of learning media with indicators of subject matter, ease of use, attractive packaging, and up to date. The fact shows that the use of conventional learning media in the process of practical learning is still mostly found in the vocational school environment.

S. Samani M [3] Based on preliminary studies conducted through interviews with study programs, several teachers, and students of Audio Video Engineering, the results showed that: (1) the main obstacle for teachers when delivering subject matter is learning media that cannot operate optimally when the learning process is taking place; (2) conditions of learning media that are less feasible, including some parts that have been damaged; (3) the number of learning media that are not in accordance with the number of students in the practice class; (4) the level of student understanding that is unevenly related to productive subjects, so that the delivery of teaching material must adjust to each student's understanding.

Renewal of learning media is needed so that students are able to keep up with the latest technological developments that already exist. The use of LED TV media trainers, is considered appropriate to replace the conventional TV trainer media that has been used before. However, it needs to be studied further whether the LED TV trainer learning media is able to provide a difference to student competency when compared to conventional TV trainer media. Adjustment of LED TV learning media also needs to be done with indicators of treatment subject matter and audio electronics repair. This is done so that students have competencies that are in accordance with the demands of the curriculum designed by the government. [4] In addition, the use of LED TV learning media is expected to create a climate of active learning between teachers and students, because active learning can create a pleasant atmosphere, and most importantly, it can encourage students to think critically.

Based on the background described above, the formulation of the problem in this study are: (1) how is the quality of the LED TV trainer learning media developed ?; (2) how do students respond after following the learning process using LED TV trainer learning media ?; (3) how are student learning outcomes after learning using the LED TV trainer learning media?

Based on the formulation of the problem above, the objectives of this study are: (1) to describe the quality of LED TV trainer learning media on Audio Electronics Maintenance and Repair subjects at Surabaya KAL-1 Vocational School; (2) analyze the learning outcomes of students of Audio Video Engineering at Surabaya KAL-1 Vocational School; (3) describe the response of students in Audio Video Engineering at Surabaya KAL-1 Vocational School. 
The expected benefits of the results of this study are: (1) for students: have interactive learning media for practicing Audio Video Engineering majors for learning in the classroom and provide convenience for students in conducting practical learning in the classroom; (2) for teachers: LED TV trainer learning media can be used as an alternative learning media to foster student learning interest in the classroom and it is hoped that this learning media can facilitate teachers in delivering the learning process; (3) for schools: the results of research are used as evaluation material about the advantages and disadvantages of facilities and infrastructure owned by schools, improving quality in the teaching and learning process, especially in Audio Video Engineering, and knowing the situation in the world of Vocational High School education, especially in the field of technology and engineering.

Actually what is meant by learning media? [5] learning media as a technology, symbol, or equipment with unique processing capabilities. The most obvious and visible media characteristics are the selection of technology used, mechanical and electronic aspects that can determine its function, up to other forms and physical features. The ability of media that can be adapted to environmental conditions, makes it flexible, practical, and effective. Learning media that are able to adjust the demands of student competencies are expected to be able to provide interest in students in following the learning process.

Zimmerer[6] Understanding media in the teaching and learning process tends to be interpreted as graphical, photographic, or electronic tools to capture, process, and reconstruct visual or verbal information. Educational media is also emphasized on the audio and visual side as part of the appeal and flexibility of the media.

Learning media that will be used in the learning process, must meet the desired criteria and learning objectives[7]. To make a quality learning media needed the following steps: (1) analyze the needs and characteristics of students; (2) formulate operational and typical operational objectives; (3) formulate items in detail that support the achievement of objectives; (4) developing a measure of success; (5) writing the media script; and (6) conduct tests and revisions.

J. B. Craft A [8] The criteria that are the focus in preparing the media are (1) student characteristics; (2) learning goals; (3) the nature of teaching materials; (4) media effectiveness; and (5) the nature of media use. In line with the above opinion, Sudjana \& Rivai (2010, p. 4) reveal that to compile and select learning media should consider aspects that include: (1) accuracy with learning objectives; (2) support for the content of study material; (3) ease of obtaining media; (4) teacher skills in using it; (5) time availability; and (6) according to the level of thinking of students. So, there are various aspects that need to be considered in preparing a learning media, especially the trainer learning media that will be used in this study. The aspects that need to be considered in making trainer learning media for vocational students need to refer to the above opinions which include: (1) student ability; (2) learning objectives to be achieved; (3) ease of operational media; and (4) the urgency of media use.

The media used in learning must have validity. The validity of learning media depends on the ability of the media to cover the entire subject matter. In this case, the LED TV learning media must be able to include indicators and objectives for subjects of maintenance and repair of audio electronic equipment, especially in TV repair materials. In addition, the LED TV learning media must also meet the ease of operation requirements, ease in including understanding the contents and functions of LED TV sets.

Furthermore, how far are the roles and benefits of learning media? [9] Reeves concluded that the role of media is so important in the learning process. In fact, according to Reeves, media and technology have a better impact than other approaches in the world of education. 
At the end of his research report, Reeves showed that the improvement of a learning media must always be done to obtain a more positive impact.

Nurlaela [2] Tilestone in his scientific article entitled "The Importance of Media in the Classroom" concluded that more than $87 \%$ of students in the class were interested in learning using media (audiovisual). Moreover, the results of Tilestone's research also revealed that $98 \%$ of information entering the brain is through the senses. Therefore, the use of learning media is the right strategy in delivering lesson material in the classroom.

J. G. Boyd[10] Lahiji in the results of his research analysis entitled "Critical Media Education: Youth Media Production As A Space of Creativity for Lifelong Learning" revealed that good media is a media-created through a combination of observing and writing, not just about understanding, but also able to foster creativity and productivity. The use of appropriate media can influence productivity, innovation, creation, and critical thinking skills of students.

Furthermore, technology has an important role in learning activities for students and teachers[11]. Learning media as a form of new technology aims to improve the efficiency and effectiveness of delivering the basic subject matter in the classroom. Learning media must always keep up with existing technological advances so that student and teacher competencies can develop in a better direction.

Baron J B [12] The results of Sumarti's study, Pargito \& Trisnaningsih concluded that the use of audiovisual learning media was able to increase the average score of knowledge competencies by 80.66 ; average attitude competency score of $90 \%$; and the average skill competency score is 80.59 .

According to Wright, Borg \& Lauri[13] research in his journal entitled "Media Education as a tool to promote critical thinking among students" suggests that learning media are able to provide assistance to students to understand new concepts. Learning media provide new knowledge and expertise for students, so students can easily gain new experiences based on the concepts being studied.

Thus, overall learning media is able to provide a positive effect on students in the learning process in the classroom if used appropriately and in line with the learning objectives. With the learning media, students are given the convenience of understanding a concept that is abstract on a particular problem.

Every learning media has product specifications. The learning media of LED TV developed came from LED TVs with the Toshiba type 19HV15E brand. Learning media developed have appropriate specifications if taught to vocational students majoring in Audio Video Engineering. The learning media specifications are summarized in Table 1 below.

\begin{tabular}{cc}
\hline Aspect & Information \\
\hline Model & $19 \mathrm{HV} 15 \mathrm{E}$ \\
Voltage source & $110-240 \mathrm{VAC}, 50 / 60 \mathrm{~Hz}$ \\
Power consumption & $22 \mathrm{~W}, 0.5 \mathrm{~W}$ \\
Dimension & $454(\mathrm{~W}), 354(\mathrm{H}), 122(\mathrm{D}) \mathrm{mm}$ \\
Weight & $4.0 \mathrm{~kg}$ (including box) \\
Color system & PAL, SECAM, NTSC $3.58 / 4.43$ \\
Aspect ratio & $16: 9$ \\
Pixel & $1366(\mathrm{H})$ dots $\times 768(\mathrm{~V})$ dots \\
Audio power & $5 \mathrm{~W}+5 \mathrm{~W}$ \\
Speaker & Main 42 x 75 mm 2pcs \\
Connector & VGA, HDMI, RCA \\
\hline
\end{tabular}


Table 1. Specifications of Learning Media

Based on Table 1 above specifications, it can be seen that the LED TV learning media is very suitable if used as a learning media for Audio Video Engineering majors in Vocational Schools. Furthermore, the results of the development of LED TV learning media as shown in Figure 1 below.

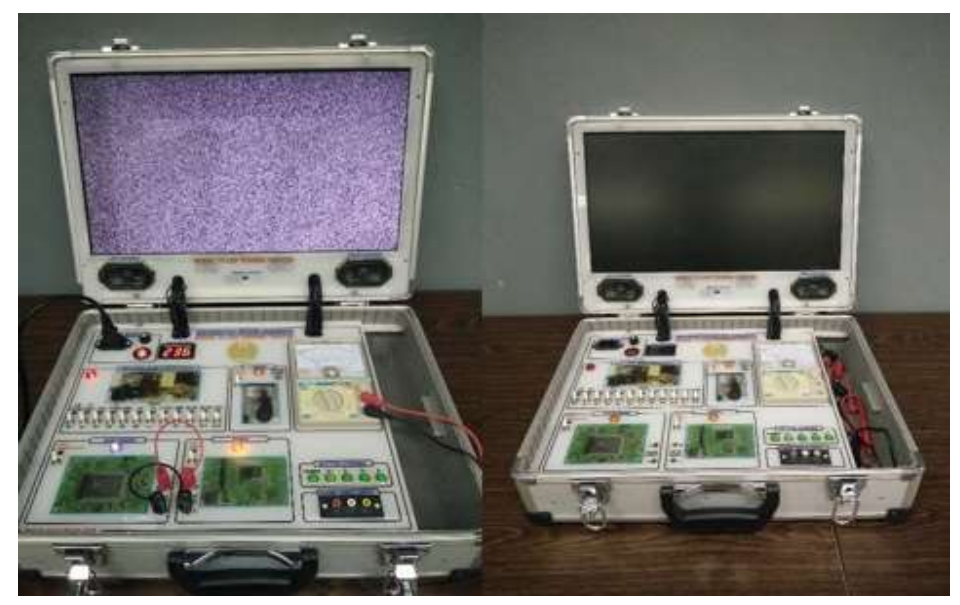

Figure 1. Results of LED TV Learning Media Development

As seen in figure 1 above, the test points found on LED TV learning media can be described as follows.

Table 2. Specifications of Learning Media

\begin{tabular}{cc}
\hline Poin Test & Information \\
\hline TP 1/ S1 & Gnd (Audio) \\
TP 2/ S2 & 15 V Audio \\
TP 3/ S3 & Gnd \\
TP 4/ S4 & 5 V T-con \\
TP 5/ S5 & Gnd \\
TP 6/ S6 & 5 V \\
TP 7/ S7 & Power TV \\
TP 8/ S8 & DC_detect \\
TP 9/ S9 & Gnd \\
TP 10/ S10 & BL_ON \\
TP 11/ S11 & Ext_dim \\
TP 12/ S12 & Stats \\
\hline
\end{tabular}

From Table 2 above, learning media can be operated by breaking and connecting the switches on the simulation board. Termination of the switch will cause damage to the LED TV which can then be observed through the screen and performance failure on the LED TV machine. Furthermore, there are voltage measurement points (test points) found on LED TV learning media. The measurement point can be measured using the AVO meter and functions to find out the supply voltage of each LED TV circuit block. 


\section{Method}

This research is included in development research (R \& D). Products developed in the form of LED TV trainer learning media and learning modules. [14] This study uses seven stages from all stages in the R \& D process. Broadly speaking, the research procedures are briefly summarized as shown in Table 3 below.

Table 3. Research Procedures

\begin{tabular}{lc}
\hline \multicolumn{1}{c}{ Steps of $\mathbf{R} \mathbf{D}$} & Activity \\
\hline $\begin{array}{l}\text { 1. Research and information } \\
\text { gathering }\end{array}$ & Preliminary studies \\
\hline 2. Planning & $\begin{array}{c}\text { Designing a learning } \\
\text { device and media }\end{array}$ \\
\hline $\begin{array}{l}\text { 3. Develop the initial form of the } \\
\text { product }\end{array}$ & Validasi dan revisi \\
\hline 4. Test the initial product & $\begin{array}{c}\text { Empirical trials and } \\
\text { final revisions }\end{array}$ \\
\hline 5. Revised the main product & \\
\hline 6. Test the main product & \\
\hline
\end{tabular}

The empirical trial design of the learning media developed was carried out by using the research design The One Group Pretest-Posttest Design. Borg and Gall (1983) suggested that the pretest and posttest research designs were used to determine the effectiveness and quality of the learning media developed. [15] The design of the study is shown in Figure 2 below.

\begin{tabular}{|ccc|}
\hline $\mathrm{O}_{1}$ & $\mathrm{X}$ & $\mathrm{O}_{2}$ \\
Pretest & Treatment & Posttest \\
\hline
\end{tabular}

Figure 2. Research Design The One Group Pretest-Posttest Design

The study was conducted at KAL 1 Surabaya Vocational School, located at Kodiklatal Morokrembangan, Surabaya. The study was conducted in the odd semester of the 2018/2019 academic year, namely in August-November 2018. The population in this study were students of class XII Vocational School of Audio Video Engineering who applied the same curriculum (Curriculum 2013) in Indonesia. The target population is the XII grade Vocational Audio Video Engineering students who apply the 2013 curriculum throughout the city of Surabaya, with an affordable population of students in class XII Surabaya KAL 1 Vocational School of Audio Video 2018/2019 academic year with a population of 38 students. Furthermore, the research sample was taken by simple random sampling technique which can be calculated using the following equation.

$$
\mathrm{n}=\frac{N}{1+N e^{2}}
$$

Figure 3. Simple Random Sampling Technique

The total population of KAL 1 Vocational Audio Video Engineering Department if calculated using the sampling formula with a real level of 5\%, then the number of samples obtained is 35 students. While the instruments and data analysis techniques used in this study 
included learning outcomes test sheets, student response questionnaire sheets, and validation sheets. Test instruments and data collection techniques used in this study, as shown in Table 4 below.

Table 4. Techniques and Data Collection Instruments

\begin{tabular}{ccl}
\hline Data Collection Technique & Instrument & \multicolumn{1}{c}{ Information } \\
\hline Observation and interview & $\begin{array}{c}\text { Learning media } \\
\text { observation sheet and } \\
\text { interview sheet }\end{array}$ & $\begin{array}{l}\text { Data collection on learning media conditions } \\
\text { and abilities of students in the VHS KAL 1 } \\
\text { Surabaya school }\end{array}$ \\
\hline Validation & $\begin{array}{c}\text { Learning media } \\
\text { validation sheet }\end{array}$ & $\begin{array}{l}\text { Used to describe the quality of learning } \\
\text { media developed }\end{array}$ \\
\hline Test & $\begin{array}{c}\text { Student learning } \\
\text { outcomes test sheet }\end{array}$ & $\begin{array}{l}\text { Used to analyze student learning outcomes } \\
\text { before and after being taught using LED TV } \\
\text { trainer media }\end{array}$ \\
\hline Questionnaire & $\begin{array}{c}\text { Student response } \\
\text { questionnaire sheet }\end{array}$ & $\begin{array}{l}\text { Used to describe the response of students } \\
\text { taught using LED TV learning media }\end{array}$ \\
\hline
\end{tabular}

\section{Result and Discussion}

The first stage carried out in this study was the preliminary study phase through the method of observation and interview with the Head of Study Program, Teachers and Students majoring in Audio Video Engineering at KAL 1 Surabaya Vocational High School. Based on the results of observations and interviews obtained data that the learning media of TV trainers in KAL-1 Vocational School still use conventional TV and are not feasible to be used in the practical learning process in the classroom. Learning media are also not accompanied by learning modules so that teachers and students have difficulty achieving the set learning goals. Thus, it can be concluded that the teachers and students of Audio Video Engineering require LED TV trainer learning media to carry out practical activities in order to improve their learning outcomes. The second stage is the stage of designing the design of LED TV trainer learning media. At this stage, the design of learning media is carried out in accordance with the results of preliminary studies that have been carried out before, namely trainer learning media must be adapted to the 2013 learning and curriculum objectives. Aspects and indicators that need to be considered in designing instructional media designs the ability of learners; (2) learning media in accordance with curriculum objectives; and (3) ease of operation of learning media.

\subsection{Results of Learning Media Validation}

The third stage is the stage of validation and revision of LED TV trainer learning media and learning modules. Learning media developed in good /valid category with a mean score of validation results are (1) of 3.19 for validator 1 ; (2) amounting to 3.88 for validator 2; and (3) equal to 3.69 for validator 3 . Thus it can be concluded that the LED TV trainer learning media developed is feasible to use with a slight revision. Suggestions from expert validators include: (1) need to improve packaging and neatness of learning trainer cabling; (2) the need for more complex LED TV trainer media functions related to symptoms and damage analysis; and (3) need to adjust learning indicators with LED TV trainer media. The results of the validation of LED TV learning media developed are presented in Figure 4 below. 


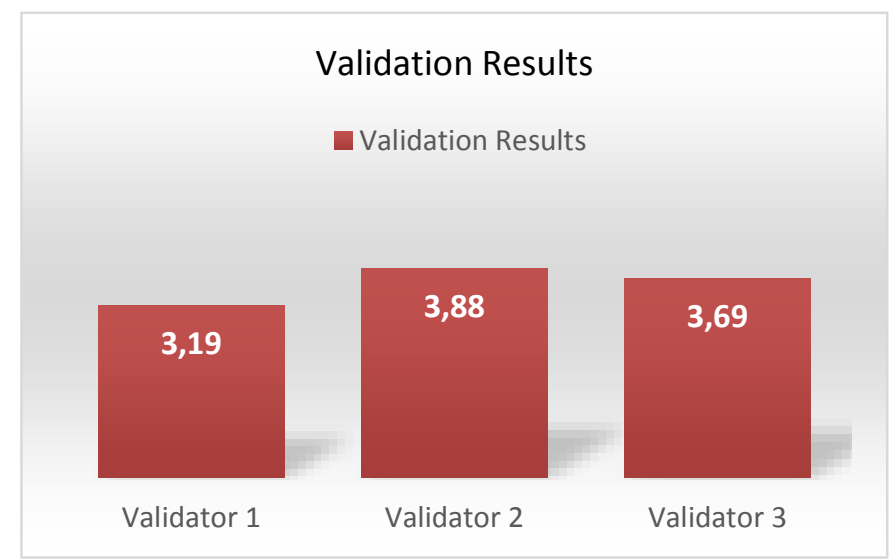

Figure 4. Graph of Media Validation and Learning Device Results (Based on Validators 1,2 and 3)

The fourth stage is the stage of empirical trials and final revisions. At this stage, the LED TV trainer learning media and learning modules are tested on students in the teaching and learning process in the classroom. The results of empirical trials are (1) student responses to LED TV trainer learning media; and (2) student learning outcomes. Student learning outcomes are measured through assessment before and after being taught using learning media (pretestposttest). Student learning outcomes before and after participating in learning using media as presented in Table 5 below.

Table 5. Student Pretest-Postest Values

\begin{tabular}{ccccc}
\hline & \multicolumn{4}{c}{ Score } \\
\cline { 2 - 5 } Student Number & Pre-test & Inf & Post-test & Inf \\
\cline { 2 - 5 } & 20 & TL & 76 & L \\
\hline 1 & 28 & TL & 78 & L \\
3 & 16 & TL & 77 & L \\
4 & 40 & TL & 80 & L \\
5 & 22 & TL & 82 & L \\
6 & 6 & TL & 88 & L \\
7 & 18 & TL & 84 & L \\
8 & 4 & TL & 87 & L \\
9 & 40 & TL & 86 & L \\
10 & 36 & TL & 89 & L \\
11 & 30 & TL & 76 & L \\
12 & 56 & TL & 79 & L \\
13 & 24 & TL & 70 & TL \\
14 & 24 & TL & 80 & L \\
15 & 22 & TL & 84 & L \\
16 & 20 & TL & 66 & TL \\
17 & 6 & TL & 60 & TL \\
18 & 8 & TL & 78 & L \\
19 & 16 & TL & 98 & L \\
20 & 12 & TL & 100 & L \\
21 & 18 & TL & 99 & L \\
22 & 28 & TL & 80 & L \\
23 & 6 & TL & 86 & L \\
24 & 14 & TL & 84 & L \\
25 & 26 & TL & 88 & L \\
26 & 20 & TL & 90 & L \\
27 & 26 & TL & 96 & L \\
28 & 22 & TL & 94 & L \\
29 & 20 & TL & 70 & TL \\
30 & 18 & TL & 78 & L \\
31 & 16 & TL & 76 & L \\
32 & 18 & TL & 80 & L \\
\hline & & & & \\
\hline & & & & \\
& & & &
\end{tabular}




\begin{tabular}{ccccccc}
\hline 33 & 16 & & TL & 88 & L \\
34 & 28 & TL & 89 & L \\
35 & 22 & & TL & 54 & & TL \\
Mean & & $\mathbf{2 1 . 3 1}$ & & & $\mathbf{8 2 . 0}$ & \\
\hline
\end{tabular}

From Table 5 above, the average pretest score of students is 21.31 ; while the average posttest score is 82.0. There were no students who passed the pretest assessment, while for the posttest there were 31 students who graduated and 4 students who did not pass. Next, to find out whether there are differences in the average score of student learning outcomes before and after learning using the LED TV trainer learning media, t-test statistical techniques (paired samples t-test) are used. Prerequisite tests are carried out first before data analysis is carried out. The first condition test is the normality test as presented in Table 6 as follows.

Table 6. Test Results for Normality of Pretest and Posttest Data

\begin{tabular}{|c|c|c|c|}
\hline \multicolumn{4}{|c|}{ One-Sample Kolmogorov-Smirnov Test } \\
\hline \multirow{2}{*}{\multicolumn{2}{|c|}{$\mathrm{N}$}} & Pretest & Posttest \\
\hline & & 35 & 35 \\
\hline \multirow[t]{2}{*}{ Normal Parameters ${ }^{\mathrm{a}, \mathrm{b}}$} & Mean & 21.31 & 82.00 \\
\hline & Std. Deviation & 10.671 & 10.241 \\
\hline \multirow[t]{3}{*}{ Most Extreme Differences } & Absolute & .132 & .136 \\
\hline & Positive & .132 & .076 \\
\hline & Negative & -.109 & -.136 \\
\hline \multicolumn{2}{|l|}{ Test Statistic } & .132 & .136 \\
\hline \multicolumn{2}{|c|}{ Asymp. Sig. (2-tailed) } & $.132^{\mathrm{c}}$ & $.099^{\mathrm{c}}$ \\
\hline
\end{tabular}

a. Test distribution is Normal.

b. Calculated from data.

c. Lilliefors Significance Correction.

From Table 6 above it can be seen that from the pretest results obtained a significance of 0.132 , a significance of $0.132>$ from 0.05 so that $\mathrm{H}_{0}$ is accepted and $\mathrm{H}_{1}$ is rejected. So, it can be concluded that the pretest score of student learning outcomes comes from populations that are normally distributed. Furthermore, the posttest results obtained a significance of 0.099 , a significance of $0.099>$ from 0.05 so that $\mathrm{H}_{0}$ was accepted and $\mathrm{H}_{1}$ was rejected. So, it can be concluded that the posttest score of student learning outcomes, comes from a population that is normally distributed. The graph of the normal curve of the pretest and posttest scores as shown in Figure 5 below.
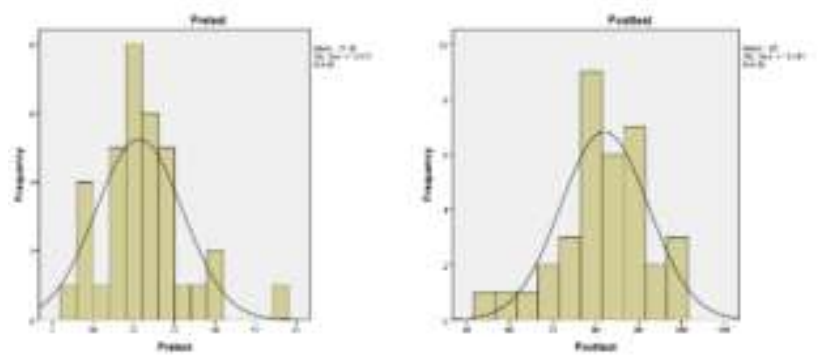

Figure 5. Normal Curve Pretest and Posttest Score Student Learning Outcomes

The second condition test is a test of the variance homogeneity of student learning outcomes data. The homogeneity test was carried out on the results of the student's pretest and posttest assessment. The test results of variance homogeneity are presented in Table 7 below. 


\begin{tabular}{cccc}
\hline \multicolumn{4}{c}{ Test of Homogeneity of Variances } \\
\hline \multicolumn{4}{c}{ Learning Outcomes Students } \\
\hline Levene Statistic & df1 & df2 & Sig. \\
\hline .011 & 1 & 68 & .918 \\
\hline
\end{tabular}

Table 7. Homogeneity Variance Test Results

\subsection{Analysis of Student Learning Outcomes}

After the requirements test is carried out and student learning data meet the parametric statistical test requirements (data are normally distributed and have homogeneous variances), then the next step is to analyze the data using t-test statistical techniques (paired samples ttest). T-test results (paired samples t-test) are presented in the table below.

\begin{tabular}{cccc}
\hline \multicolumn{4}{c}{ Paired Samples Test } \\
\hline & $\mathrm{T}$ & df & Sig. (2-tailed) \\
\hline Pretest - Posttest & -24.074 & 34 & .000 \\
\hline Table 8. T-Test Results (Paired Samples T-Test)
\end{tabular}

The results of the statistical test on the learning outcomes of the pretest and posttest were conducted using paired samples t-test obtained significance of 0,000 . The significance is 0.000 $<0.05$ so that $\mathrm{H}_{0}$ is rejected and $\mathrm{H}_{1}$ is accepted. Thus, it can be concluded that there are differences in the average student learning outcomes before and after participating in learning using LED TV trainer learning media. Based on the results of the score analysis students who learn using LED TV learning media, show that LED TV media have a good impact on student scores. The positive impact arises due to the interest of students to learn better when there are learning media that are able to support practical learning activities in the classroom. [13] Learning media is able to provide assistance to students to understand new concepts. [8] Learning media that are effective, easy, and include all indicators are good and quality learning media. Learning media that are right on target are learning media that are able to direct students to learn more easily with a simple understanding even though the subject matter being taught is classified as complex[10]. Good media is a media-created through a combination of observing and writing activities, not only about understanding but also able to foster creativity and productivity.

\subsection{Student Response}

Students' responses to the learning process in the classroom using LED TV trainer learning media showed positive results with a percentage of responses of $84.4 \%$, a percentage of $84.4 \%$ indicating that LED TV trainer learning media were able to facilitate students in understanding the concepts and ways of working LED TV. Thus, it can be concluded that LED TV trainers that have been developed have a positive impact on the learning process of students in Surabaya's Audio Video Engineering Department of KAL-1. Positive responses of students to LED TV trainer learning media show that students are aware of the importance of 
competencies that must be mastered in order to face life in the 21 st century which must work productively based on their competencies[16]. But working productively is not enough, because 21 st-century workers must be able to build services that are fast, careful, smart and satisfying to customers. Therefore students must study anywhere and anytime, through various learning media, including using e-learning[17]. In line with the findings of Soeparno \& Muslim that learning media that embodies e-learning as a learning media in building techniques has advantages because it can be accessed anytime and anywhere, materials and tasks can be obtained easily, and are efficient in communication and discussion. Therefore 21 st-century vocational learning must be designed to provide an impressive learning experience, so that students: (1) know what is done; (2) willing and able to do what must be done; and (3) aware or aware, why should it be done. [18] Such learning experiences will support the acquisition of life skills in a practical manner, thus making students more aware of the context of their work and better able to capture opportunities, as a provision for prospective entrepreneurs to establish social or commercial activities.

\section{Conclusion}

Based on the analysis that has been carried out on the research data, it can be concluded that: (1) LED TV trainer learning media and learning modules are declared valid/good and worthy of being used for classroom learning; (2) there is a very significant difference in the average score of student learning outcomes between before and after learning using the LED TV trainer media; and (3) the response of students to the LED TV trainer learning media used in the classroom was $84.4 \%$.

\section{Suggestion}

Based on the results of this study, some suggestions that can be given are: (1) students need learning media in understanding the concepts, functions, and uses of electronic equipment, so that other media are needed that can grow students' enthusiasm in learning in the classroom; (2) the use of learning media is very very influential in managing learning in the classroom, so that teachers and students can interact optimally during the learning process; (3) the latest technology-based learning media need to be used, because in the 21 st century, the world has entered the industrial era 4.0, which means that the use of information and communication technology is needed in order to complete tasks and daily work.

\section{References}

[1] Rasto, "Pendidikan kejuruan," 12AD.

[2] Tilestone, "The importance of media in the classroom," vol. 9, pp. 1-7, 2003.

[3] D. Mahesa P, "Personal note of researcher," 2018.

[4] R. Duron, B. Limbach, and W. Waugh, "Critical thinking framework for any discipline," Int. J. Teach. Learn. High. Educ., vol. 17, no. 2, pp. 160-166, 2006.

[5] R. B. Kozma, "Learning with media," Rev. Educ. Res., vol. 61, no. 2, pp. 179-212, 1991.

[6] A. Arsyad, Media Pembelajaran. Jakarta: Raja Grafindo Persada, 2010.

[7] A. S. Sadiman and R. H. A. Rahardjo, Media pendidikan: pengertian, pengembangan, 
dan pemanfaatannya. Jakarta: Raja Grafindo Persada, 2014.

[8] Y. Munadi, Media pembelajaran; sebuah pendekatan baru. Jakarta: Gaung Persada Press, 2012.

[9] T. C. Reeves, "The impact of media and technology in schools," J. J. Art Des. Educ., vol. 2, pp. 58-63, 1998.

[10] A. Lahiji, "Critical media education: youth media production as a space of creativity for lifelong learning," Department of Interdisciplinary StudiesUniversity of Saskatchewan, 2008.

[11] K. Courville, "Technology and its use in education present roles and future prospects," in Recovery School District Technology Summit, 2011, pp. 1-19.

[12] P. \& T. Sumarti, "Penggunaan media audio visual untuk meningkatkan motivasi dan hasil belajar," Artik. Penelit. PTK, 2014.

[13] E. Wright, J. Borg, and M. A. Lauri, "Media education as a tool to promote critical thinking among students," J. Educ. media, vol. 2, pp. 62-72, 2015.

[14] W. R. Borg, M. Gall, and N. D. Wallen, Educational research: an introduction. New York: Longman, inc, 1983.

[15] J. R. E. Fraenkel, How to design and evaluate research in education. New York: McGraw-Hill Companies, 2006.

[16] P. Sudira, Metodologi pembelajaran vokasional abad XXI: Inovasi, teori dan praktis. Yogyakarta: UNY Press, 2018.

[17] S. Muslim, "Effectiveness of e-learning for students vocational high school building engineering program," IOP Conf. Ser. Mater. Sci. Eng., vol. 336, no. 1, 2018.

[18] A. S. Usman and R. Tasmin, "Entrepreneurial skills development strategies through the mandatory students industrial work experience scheme in Nigeria," Procedia - Soc. Behav. Sci., vol. 204, pp. 254--258, 2015. 